\title{
THE RELATIONSHIP BETWEEN HAZELNUT PRICES AND FINANCIAL PERFORMANCE OF COMPANIES AND THE MODERATE EFFECT OF FOREIGN EXCHANGE RATE ON THIS RELATIONSHIP*
}

\author{
Asst. Prof. Murat BERBEROĞLU** \\ Artvin Coruh University, FEAS, Artvin, Turkey (murat@artvin.edu.tr) \\ Asst. Prof. Uğur UZUN \\ Artvin Coruh University, FEAS, Artvin, Turkey (uguruzun@artvin.edu.tr)
}

\begin{abstract}
The great majority of hazelnut harvest in the world are grown in Eastern Black Sea region of Turkey and it is very important for region economy. In the past, Fiskobirlik was effective to determine the base price of hazelnut but now it has been determined by the free market based on the harvest amount. In this context, prices are different each year. It is discussed that how this difference price does affect the financial performance of firms. From this point, it is tried to examine the impact of hazelnut prices on the financial performance of firms operating hazelnut industry in Turkey. In the study, companies that are in the hazelnut sector within the 1000 most successful firms registered with Istanbul Chamber of Industry (ISO) have been analyzed.
\end{abstract}

Keywords: Financial Performance, Export, Exchange Rate, Moderator, Hazelnut.

\section{FINDIK FIYATLARI İLE ŞİRETLERIN FINANSAL PERFORMANSI ARASINDAKİ İLIŞKİ VE DÖVIZZ KURUNUN BU İLIŞKI ÜZERINDEKI MODERATÖR ETKİSI}

\begin{abstract}
ÖZET
Dünya findık üretiminin büyük çoğunluğu Türkiye’nin Doğu Karadeniz Bölgesinde yapılmaktadır ve bölge ekonomisi için çok önemlidir. Geçmişte findık taban fiyatlarının belirlenmesinde Fiskobirlik etkili olurken günümüzde fiyatlar rekolteye göre serbest piyasada belirlenmektedir Bu bă̆lamda fiyatlar her yıl farklıdır. Bu farklı fiyatların firmaların finansal performansını nasıl etkilediğ $i$ tartışılmaktadır. Bu noktadan hareketle çalışmada findık fiyatlarının Türkiye'de findık alanında çalışan firmaların finansal performanslarına etkisi araştırılmaya çalışılmıştır. Çalışmada, İstanbul Sanayi Odası'na (ISO) kayıtlı en başarılı 1000 firma içinde findik sektörüinde yer alan şirketler analiz edilmiştir.
\end{abstract}

Anahtar Kelimeler: Finansal Performans, İhracat, Döviz Kuru, Moderatör, Fındık.

\footnotetext{
* The draft of this study presented at the international Congress on Management Economics and Business held on 7-9 September 2017 at Bulent Ecevit University (Zonguldak). Also This study was supported by Scientific Research Coordinator of Artvin Coruh University in 2017 with project number 2016.S50.02.11

** Corresponding author
} 


\section{Introduction}

Hazelnut is one of the most widely used nuts in the world. These elements, such as fruit, crust, oil and leaf can be used in many areas. Therefore, it is too important for Turkey (Sinav, 2013:1). According to the Food and Agriculture Organization (FAO) world hazelnut production is taking place in Turkey, Italy, Spain, USA, Chile, China, Iran, Greece, France, Azerbaijan, Russia and Georgia (Turkish Grain Board, Hazelnut Sectorial Report, 2015:2). Approximately $80 \%$ of this production is used in the chocolate industry, $10-12 \%$ is used in pastry, biscuit and bakery products, $3-4 \%$ is dried and the rest is used in ice cream and oil production (Trabzon Exchange Commodity, 2014:13).

According to Turkish Grain Board's (TMO) data, as of 2015, 67\% of world hazelnut production occur in Turkey. This situation is very important for the Black Sea Region' economy and provides income for 400.000 farmers' families. A large majority of hazelnuts are exported. For this reason, many hazelnut firms in the region are interested in this issue. The cost of hazelnuts for these companies can change every year depending on prices of hazelnut.

Hazelnut prices are determined according to factors such as domestic and international demand, product quantity (yield) and cost. Especially weather and climatic conditions are an effective factor in production quantity. The difference in production can cause the prices to change. In 2014, adverse weather conditions experienced in Turkey have caused a decrease in production and hazelnut prices have increased. The prices, which are around 6 TRY in 2013, exceeded 15 TRY in 2014.

In Figure 1 below, the trend of average hazelnut stock market prices in Turkey in 20112015 period can be seen in quarterly periods. As you can see, the highest price up to now was realized at the end of 2014 with 18,88 TRY.

Figure 1: Turkey Hazelnut Prices (Average)

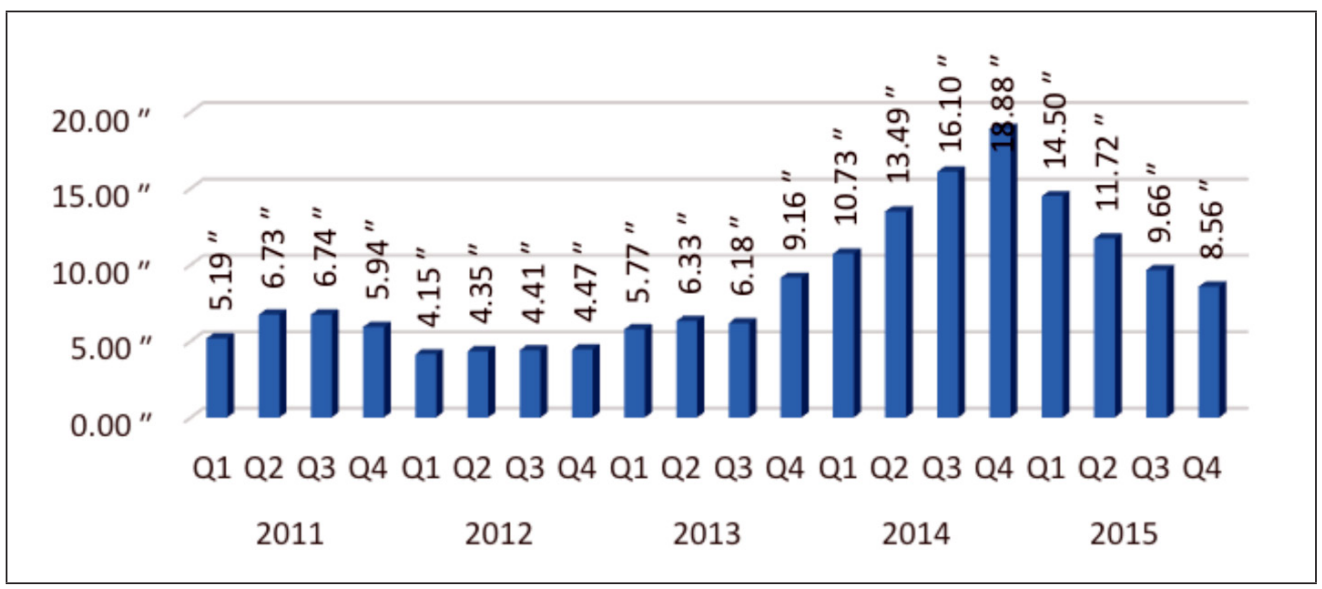

Source: The database of The Union of Chambers and Commodity Exchanges of Turkey 
Volatility in hazelnut prices is one of the most important issues for hazelnut sector. In this study, it is aimed to determine the relationship between hazelnut prices and performance of firms working in hazelnut sector. For this purpose, 20 years' data of 18 firms operating in the hazelnut field in the İstanbul Chamber of Industry 1000 (Top 1000 Industrial Enterprises of Turkey) list have been used. Panel data analysis is preferred as the most appropriate method when the feature of the data set is taken into consideration.

Due to Turkey's place in the world hazelnut production, hazelnut subject is discussed in academic studies. However, the number of studies examining the effect of hazelnut prices on business performance is limited in the literature. In this context, it is considered this study will contribute to the literature.

\section{Statistical Information on Hazelnut Product in the World and Turkey}

From the 1960s to the present day, as seen in Figure 2, world hazelnut production has increased significantly. The graph is given below;

\section{Figure 2: World Hazelnut Production (Ton)}

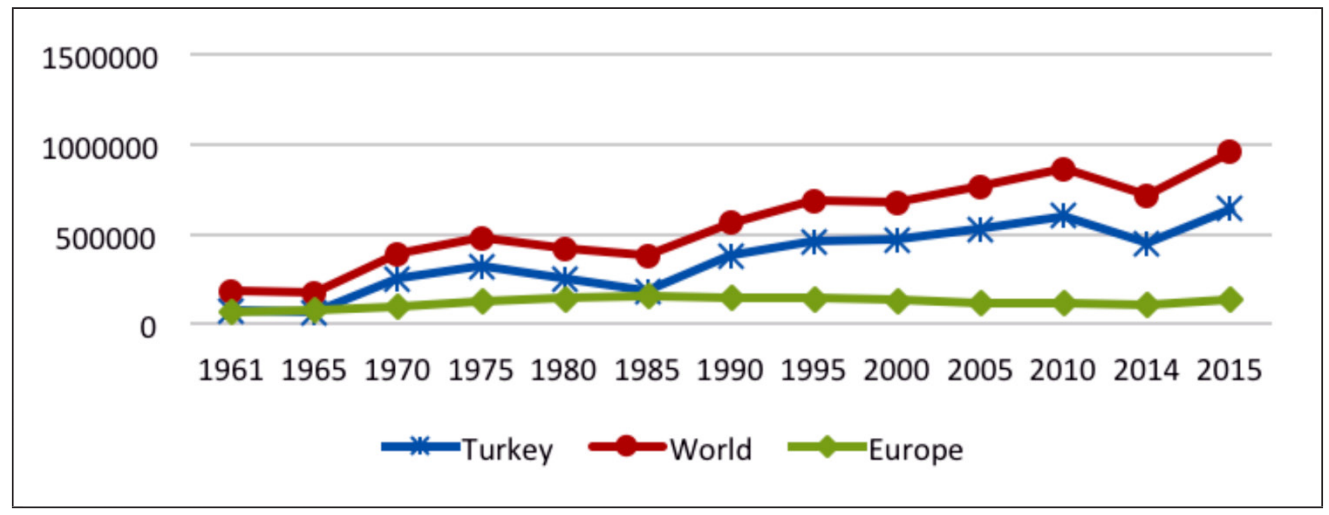

Source: Food and Agriculture Organization of the United Nations and the International Nut \& Dried Fruit Council

According to Food and Agriculture Organization statistics, world hazelnut production, which was 182.275 tons in 1961, has increased by about 4 times to 713.451 tons in 2014 and 955.224 tons in 2015. During this time, amount of hazelnut production In Turkey has increased much more than World production. The production increased from 76.000 tons in 1961 to 450,000 tons in 2014 and 640.000 tons in 2015 (Zaman, 2004: 67). Turkey is the leader with a share of $65-70 \%$ in world hazelnut production according to the in Figure 3 . Therefore, it can be said that Turkey's market share increased over time in the world hazelnut market. The Shares of Turkey in World Hazelnut Production are given in Figure 3. 
Figure 3: The Share of Turkey in World Hazelnut Production

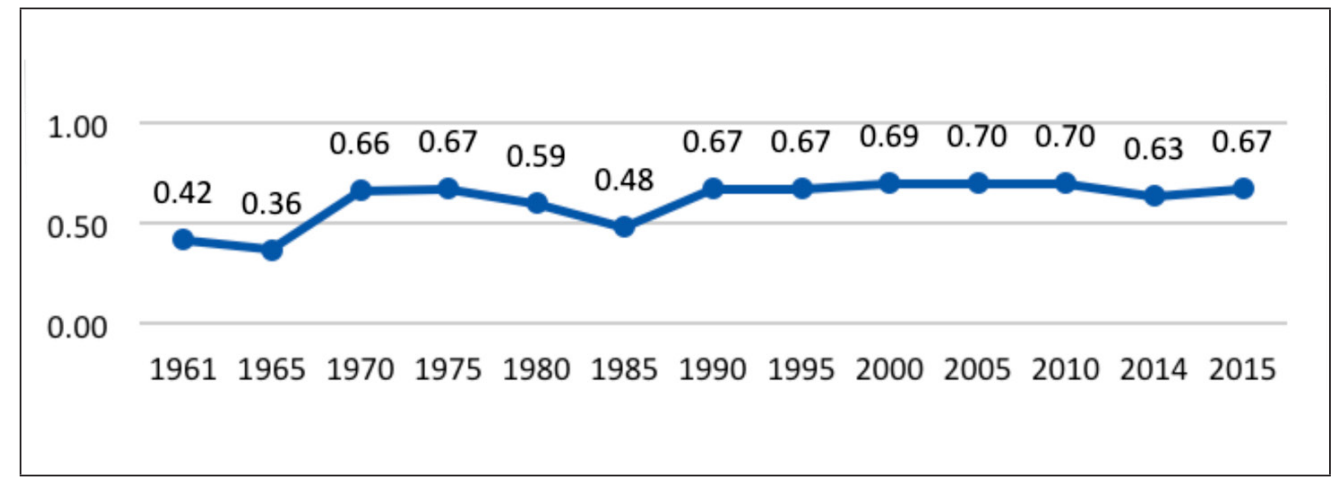

Source: Food and Agriculture Organization of the United Nations

The share of Turkey, which was 42\% in 1961, reached $67 \%$ in 1990 and maintained this level in the following years. In 2015, the share of Turkey in world hazelnut production was approximately $67 \%$. Turkey is also the country with the highest export of hazelnut product. As can be seen in Figures 4 in the last 50 year period, Turkey carries $70 \%-75 \%$ of world hazelnut exports on average.

Figure 4: Turkey's Share in World Hazelnut Exports (Ton)

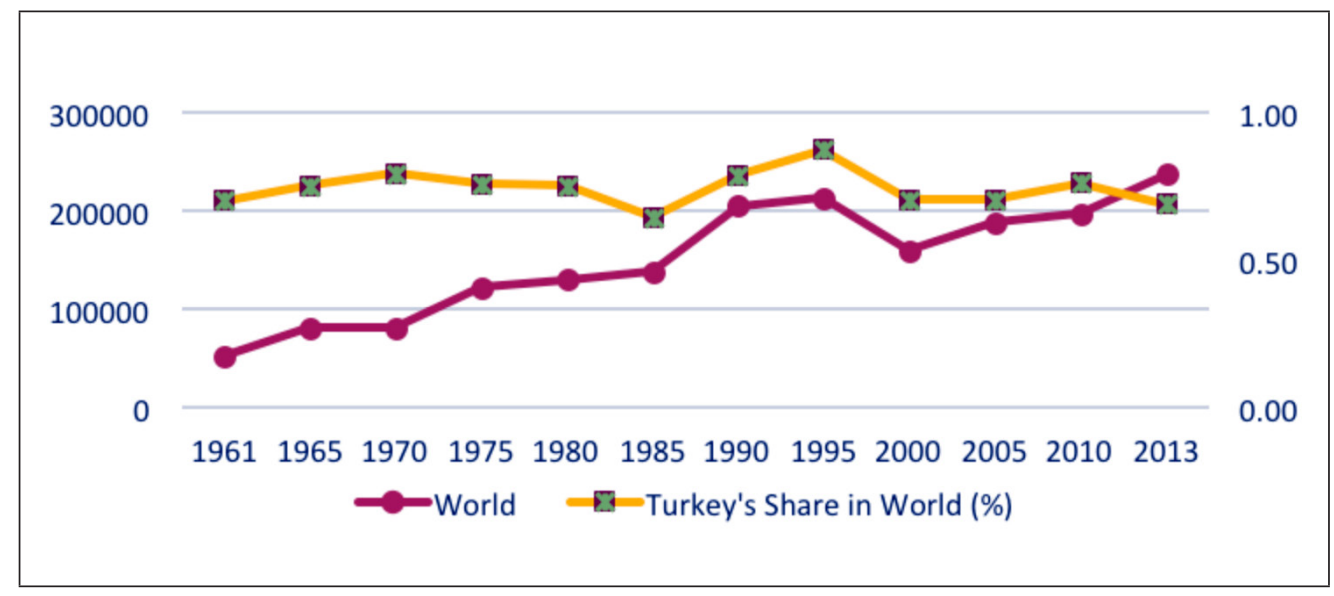

Source: Food and Agriculture Organization of the United Nations

Figure 5 shows the export values and export quantity of 2005-2016 periods. Accordingly, the amount of hazelnut exported does not differ much from the period. When export values are examined, significant differences are seen in years. The main reasons for this situation are the variability in hazelnut prices and fluctuations in exchange rates. 
Figure 5: Turkey's Hazelnut Export Quantity (Ton) and Export Values (Hazelnut Kernels)

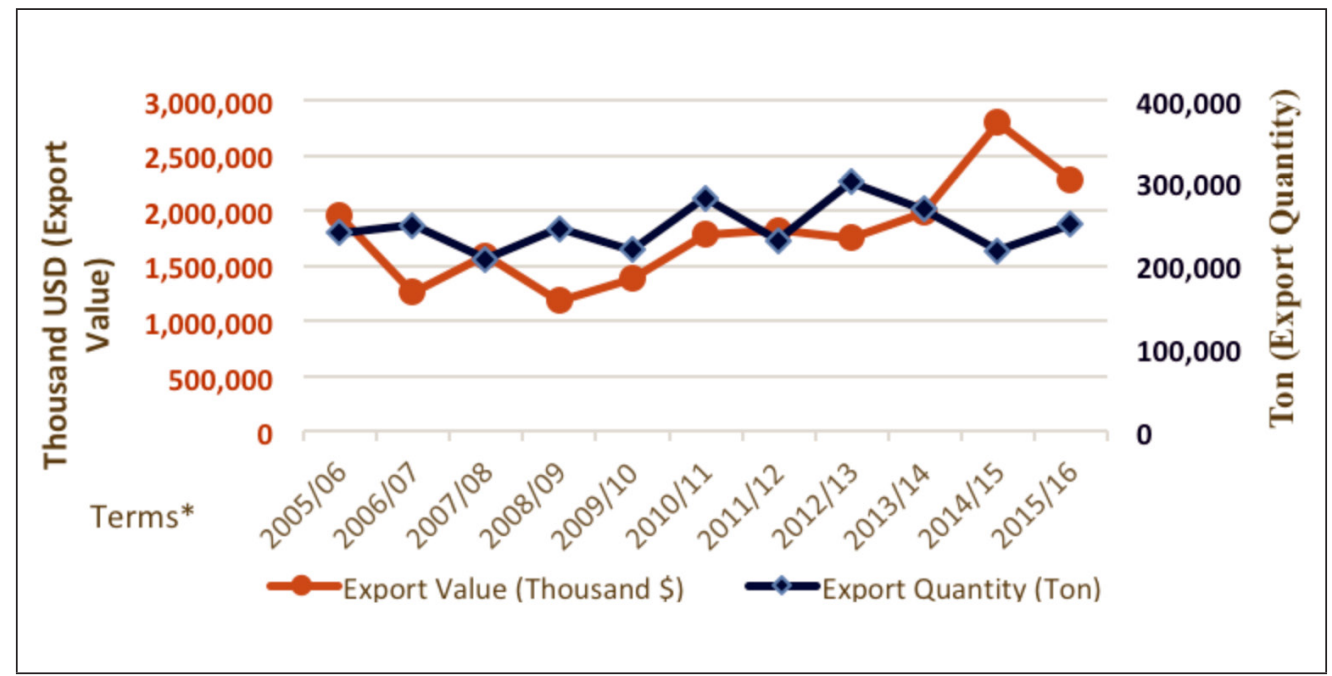

* The periods start from the first day of the 9th month of the first year and include the last day of the 8th month of the following year

Source: KIB (General Secretariat of Black Sea Exporters Associations)

According to the information provided by the International Nut \& Dried Fruit Council database, the main hazelnut importers in the world are Italy with $21.5 \%$ of total imports, Germany with $18 \%$, France with $10 \%$, Russia with $4,4 \% 4.3 \%$ are from Belgium and 3,7\% from Switzerland. Especially, these countries are demanding the nuts intensively because they are developed for the chocolate and candy industry. In addition to these countries, Canada is seen as an important importer of hazelnuts in recent years.

\section{Model, Literature, and Hypotheses of Research}

\subsection{Model of the Research}

The main activity of hazelnut companies in Turkey is hazelnut purchase and sale. For this reason, it can be said that the changes in the prices of nuts can directly affect their performances. Moreover, the performance of these companies may also be affected by hazelnut prices outside of Turkey. Therefore, it was tried to examine the effect of the prices of hazelnuts in Turkey and Italy, which is the second highest producing country after Turkey, on the performance data. In addition, the exchange rate has been added as a moderator variable to determine whether the changes in the exchange rates affect this relationship. 
The model of the research on this information is as follows;

Figure 6: Research Model

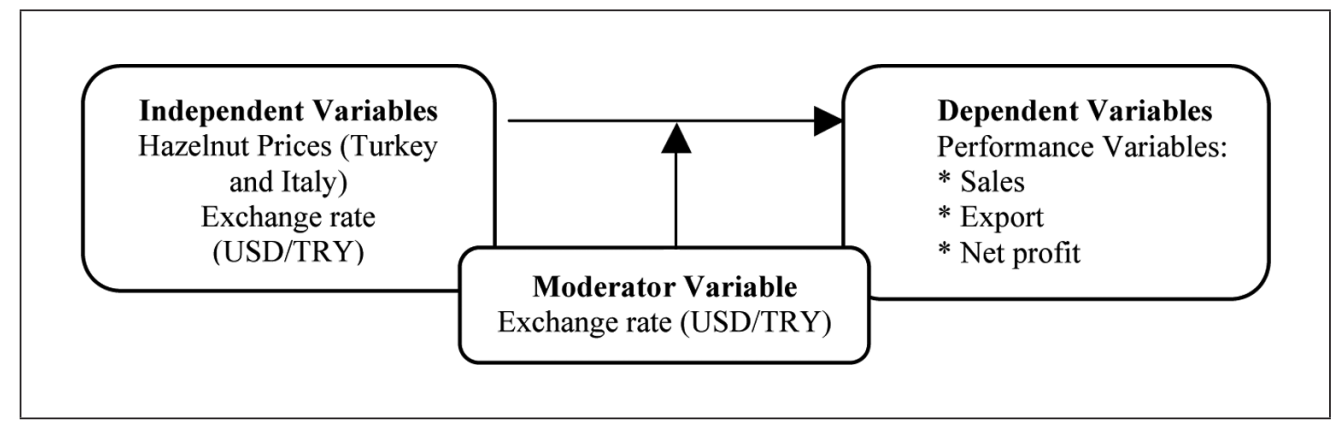

\subsection{Literature}

Turkey's great contribution to world hazelnut production and trade makes it necessary to carry out various studies on this product. In this context, there are very few studies examining the effects of hazelnut prices on the performance of hazelnut processing or firms that are working on hazelnut operations. Some studies on hazelnut product are given below.

Erdal \& Uzunoz (2008: 47) investigated the relationship between Turkey's hazelnut export prices, exchange rate and European hazelnut stock prices in 1995-2007 with causality analysis. The real effective exchange rate, Turkish hazelnut export prices, and European Hamburg Stock Exchange hazelnut prices series were used in the study. First, it has been determined that there is a long-run relationship between the variables. As a result of the Granger causality analysis, one-way causality was determined by the exchange rate and Turkish hazelnut export prices to European hazelnut stock prices. Moreover, there is a twoway causality relationship between Turkey and European hazelnut prices.

Bayramoğlu \& Gündoğmuş (2007: 71) studied the factors that affect the price formation in the world hazelnut market and the role of Turkey in this price formation. In this context, the export and import amounts of the countries that most import and export of nuts and the currencies of these countries' parity against the dollar have been examined through VAR method. As a result of the study covering the years 1970-2004, it has been determined that world hazelnut prices are influenced by the value of the country's money against the dollar, Turkey's hazelnut production amount and Fiskobirlik prices.

Turkey is the leader in hazelnut production and exports in the world. However, the Hamburg hazelnut stock market in Germany plays an important role when world hazelnut prices are determined. In this direction, Hatırlı et al. (2008: 143) examined the permeability of hazelnut prices between Turkey and Germany between 1996 and 2006 with the aid of a logarithmic model. The findings show that the $1 \%$ change in Turkish hazelnut prices is caused by a change of less than $1 \%$ in the Hamburg stock market and that the price gap between Turkey and Germany is lacking. This is explained by the fact that hazelnut is a stackable product and that importer countries can stockpile it. 
Güney (2014: 23) has examined production, marketing, competition, and trade conditions of hazelnut in Turkey. As a result of the study, it has been detected that there is a significant comparative advantage power of the Turkish exportation on the international market.

Fidan \& Şahinli (2010: 119), in their studies, examined the relationship between price, profit level, demand and cost about hazelnut product. For this purpose, a survey was applied to 54 enterprises and various findings were obtained. Firstly, there is a reverse relationship between the price and demand of hazelnut. According to the findings, $\% 1$ increase in price decreases the demand by \%0. 17. Second, there is a linear relationship between income per capita and hazelnut demand. In this context, the income elasticity of demand and price elasticity of demand is found. However, the income elasticity of hazelnut is quite low. Thirdly, the cost model has been established and it has been determined that variation in total cost is highly influenced by variation in variable costs.

Akseki (2014: 65) has focused on the factors that affect the world hazelnut demand. In this study, especially, has been focused costumer income with hazelnut price. In this context, the data covering the 1970-2010 period of 4 countries (Germany, Belgium, Switzerland, Italy), which have a significant share in world hazelnut imports, are used. According to the results of the panel data analysis, it is determined that hazelnut demand is not too much sense to change in the price of hazelnut and income of the countries.

Hazelnut is one of Turkey's most important export products. In this context, Çamoğlu \& Saka $(2012 ; 1)$ factors that impact on Turkey's hazelnut exports have tried to reveal. The study covers 28 companies operating in Ordu and Giresun, including hazelnut exporters. As a result of the analysis, it is determined that market and export information, the characteristics of the product, the export problems encountered abroad, the country's export procedures and policies, and the exporting country's image are effective factors in hazelnut exports for companies.

Öztürk \& Arıcı (2017: 21) have aimed to determine the problems experienced by businesses producing hazelnut of the production and marketing. The questionnaire method covering 190 enterprises was applied in the study. Findings show that the most important problems encountered in hazelnut production are the cost of input, low price of the product, and the ambiguity of the markets, respectively. In the marketing stage, the most important problems are the low price of the product in the free market and the fact that the producers do not act together.

Çelik (2014: 524) has analyzed the relationship between the price of hazelnuts and hazelnut production in Turkey. In the study covering the 1962-2013 period, it was determined, that shelled hazelnut production was affected by maximum four years" prices backward. In this context, while $1 \mathrm{TL}$ increase in shelled hazelnut prices in the current year increased shelled hazelnut production 0.031 tons, $1 \mathrm{TL}$ increase in the prices of previous year increased the production 0.016 tons, and $1 \mathrm{TL}$ increase in shelled hazelnut prices four years previously caused a 0.0023 ton increase in production. It is determined that the change in delayed values of shelled hazelnut prices, in first, second, third and fourth term has a positive effect on production but this effect reduces gradually. 


\subsection{Hypotheses of the Research}

The hypotheses established to investigate the model are as follows;

$\mathrm{H}_{1}$ : Increase in hazelnut prices affects firm's financial performance positively

$\mathrm{H}_{1 \mathrm{a}}$ : Increase in hazelnut prices affects sales income of firms positively

$\mathrm{H}_{1 \mathrm{~b}}$ : Increase in hazelnut prices affects firms' export revenues positively

$\mathrm{H}_{1 \mathrm{c}}$ : Increase in hazelnut prices affects firm profits positively

$\mathrm{H}_{2}$ : Increase in exchange rate affects firms' financial performance positively

$\mathrm{H}_{2 \mathrm{a}}$ : Increase in foreign exchange rate affects sales income of firms positively

$\mathrm{H}_{2 \mathrm{~b}}$ : Increase in foreign exchange rate affects firms' export revenues positively

$\mathrm{H}_{2 \mathrm{c}}$ : Increase in exchange rate affects net profits of firms positively

$\mathrm{H}_{3}$ : Exchange rate change affects the relationship between nut prices and financial performance

$\mathrm{H}_{3 \mathrm{a}}$ : Change in exchange rate affects the relationship between nut prices and sales income of firms

$\mathrm{H}_{3 \mathrm{~b}}$ : Change in exchange rate affects the relationship between nut prices and export incomes of firms firms

$\mathrm{H}_{3 \mathrm{c}}$ : Change in exchange rate affects the relationship between nut prices and profit of

The equations established for testing the above hypotheses are;

$$
\begin{aligned}
& Y_{1}=\beta_{1} X_{1}, \beta_{2} X_{2} \\
& Y_{2}=\beta_{3} X_{1}, \beta_{4} X_{2} \\
& Y_{3}=\beta_{5} X_{1}, \beta_{6} X_{2} \\
& Y_{1}=\beta_{7} X_{1}, \beta_{8} X_{2}, \beta_{9} X_{3}, \beta_{10} X_{1} * X_{3} \\
& Y_{2}=\beta_{11} X_{1}, \beta_{12} X_{2}, \beta_{13} X_{3}, \beta_{14} X_{1} * X_{3} \\
& Y_{3}=\beta_{15} X_{1}, \beta_{16} X_{2}, \beta_{17} X_{3}, \beta_{18} X_{1} * X_{3}
\end{aligned}
$$

Where $\mathrm{Y}_{1}$ is the sales income of the companies, $\mathrm{Y}_{2}$ is the export revenues, $\mathrm{Y}_{3}$ is the net profit, $\mathrm{X}_{1}$ is the hazelnut prices in Turkey, $\mathrm{X}_{2}$ is the hazelnut prices in Italy, $\mathrm{X}_{3}$ is the exchange rate, the $\mathrm{X} 1 * \mathrm{X} 3$ is the moderator variable 


\section{Methodology}

\subsection{The Sample of the Research}

This study was conducted in order to determine the effect of varying hazelnut prices on the performance of hazelnut companies. In this context, the problem of research is determined that "the change in hazelnut prices affects the financial performance of firms". Istanbul Chamber of Industry (ISO) published most successful 1000 companies' yearly dataset (sales, gross value added, equity, asset, profit, export...Etc.) in Turkey via an internet site ${ }^{1}$. In this data set, 18 companies working in the field of hazelnut were identified and the study was carried out on the data published between 1997 and 2014 of these firms.

Although the number of samples seems to be very small, it is realized through certain companies that dominate the nuts export market in Turkey. Accordingly, it can be said that the fluctuations in the prices of hazelnut that will be formed will be mostly on these companies. This situation can be said to spread to the general market

In addition, the data of hazelnut price in Turkey and other countries got from data published by the Food and Agriculture Organization of the United Nations (FAOSTAT).All the data are converted to dollars.

\subsection{Variables of the Research}

In the research, net profit, net sales, and export data were used to determine the financial performance of the companies. Many variables such as sales income, profitability, capacity, customer satisfaction, market share, export revenues, employee number are used in determining the financial performance in this literature (Banker et al., 2001: 324; Core et al., 1999: 380; Hoque \& James, 2000: 9, Bernard \& Jensen, 1999: 13, Park et al., 2009: 3). It can be said that the performance variables used in this context are valid.

\subsection{Analysis Method}

The fact that the number of observations is less than 30 in statistical and econometric analyses leads to a significant decrease in the analytical validity. The data set obtained to examine the effect of changes in hazelnut prices over time on firms is between 1997-2014. These data collected annually are not sufficient for analysis by the number of observations only when evaluated by the time dimension. For this reason, both the time and the number of units are considered when the data set is created. Therefore, the data of 18 firms working in the field of the hazelnuts were collected and the data set was created between these dates. In this way, the number of observations (18x19) in the data set is 342 and it is sufficient to obtain valid analysis results. The data are nominal and were converted to dollars to mitigate the negative impact of inflation. In addition, they were converted to logarithmic form except for net profit. The net profit variable has negative numbers. They do not convert to logarithmic form because of negative numbers. The smallest value of net profit is -285 million. In order to translate all of these figures into positive numbers, 300 million were added to all numbers. Thus, all figures in the net profit variable are positive. After that, net profit also was converted to logarithmic form.

1 http://www.iso500.org.tr/iso-500-hakkinda/gecmis-yil-verileri/ 
It is called a panel dataset that is formed by collecting data belonging to multiple periods of multiple firms. Analyses made with this dataset are called panel data analyses. In this context panel data analysis method is preferred for research. There is a lack of annual data of some firms in the data set. For this reason, unbalanced panel data analysis is preferred as the analysis method.

According to Tatoglu (2012b: 3); if the missing observations in the data set occur by random, the methods used for the balanced panel can be used for the unbalanced panel and the estimates are consistent. The missing data in the data set used in the research were formed by randomly. For this reason, it can be said that the methods used for the balanced panel can be used in this research analysis.

\subsection{Pre-Testing}

Certain pre-tests are required to obtain valid results in all econometric and statistical analyses. Preliminary tests to be used in this study; stationarity (unit root test), multicollinearity, estimation method selection tests, heteroscedasticity and autocorrelation tests.

\subsubsection{Stationarity (Unit Root Test)}

If the mean and variance of a time series do not change over time, the time series is stationary. When the econometric analysis is performed between non-stationary series, valid results may not be obtained. In other words, traditional $t, F$ tests, and $\mathrm{R}^{2}$ values can give erroneous results (Tatoğlu, 2012b: 199).

There are many tests to determine the stability. However, only a few of them are used for unbalanced panel data sets. In this study, Fisher Test was used to determine the presence of a unit root in the series. The results obtained are given in the table below.

Table 1: Unit Root Test Results

\begin{tabular}{lcc}
\hline & \multicolumn{2}{c}{ Chi-Squared } \\
\hline Variables & Level & 1 . The difference (D) \\
\hline Production Sales (LPS) & 24,73 & $130,78 * * *$ \\
\hline Export (LEXP) & 63,76 & $232,70 * * *$ \\
\hline Modified Net Profit (LMNP) & 144,23 & $224,25 * * *$ \\
\hline Hazelnut Prices - Turkey (LHPT) & 22,39 & $81,13 * * *$ \\
\hline Hazelnut Prices - Italy (LHPI) & 27,49 & $85,91 * * *$ \\
\hline Exchange Rate (LER) & 126,97 & $173,54 * * *$ \\
\hline
\end{tabular}

$* \mathrm{P}<0,10 ; * * \mathrm{P}<0,05 ; * * * \mathrm{P}<0,001$

According to the results in the table, all variables are stable in their first differences. Therefore, all analysis will be done with the first differences of variables. 


\subsubsection{Correlation between Variables}

In the analysis, the existence of the problem of correlation between the variables reveals the multicollinearity problem. In order to detect this problem, the state of correlation between variables needs to be examined. In this context, the analysis results are shown in the table below.

Table 2: Correlation Test Results between Variables

\begin{tabular}{lcccccc}
\hline & DLPS & DLEXP & DLMNP & DLHPT & DLHPI & DLER \\
\hline DLPS & 1 & & & & & \\
\hline DLEXP & 0,35 & 1 & & & & \\
\hline DLMNP & $-0,01$ & $-0,32$ & 1 & & & \\
\hline DLHPT & 0,33 & 0,22 & $-0,10$ & 1 & & \\
\hline DLHPI & 0,36 & 0,08 & 0,10 & 0,47 & 1 & \\
\hline DLER & $-0,11$ & $-0,14$ & 0,06 & $-0,49$ & $-0,12$ & 1 \\
\hline
\end{tabular}

According to Gujarati (2009: 336), the correlation rate between variables must be very high (e.g. 80\%) in order to be a multicollinearity problem. When we look at our table values, only the relationship between sales and export variables is greater than $80 \%$. However, these two variables are not used together in any model used for analysis. Therefore, it can be said that there is no multicollinearity problem between variables.

\subsubsection{Prediction Method Selection}

In the panel data analysis methods, it is appropriate to use the classical model (pooled) if there is no unit effect in the data set. The existence of unit activity can be determined by $\mathrm{F}$ test. Accordingly, the F test results for the estimation method selection are given below.

Table 3: Estimation Method Test Results

\begin{tabular}{ll}
\hline & F test \\
\hline Equation 1 & 0,31 \\
\hline Equation 2 & 0,47 \\
\hline Equation 3 & 0,01 \\
\hline Equation 4 & 0,29 \\
\hline Equation 5 & 0,47 \\
\hline Equation 6 & 0,01 \\
\hline
\end{tabular}

$* \mathrm{P}<0,10 ; * * \mathrm{P}<0,05 ; * * * \mathrm{P}<0,01$

According to the analyze results, the unit effect cannot be determined in the model. Therefore, it can be said that it would be appropriate to use the classic model. 


\subsubsection{Heteroscedasticity Analysis}

The existence of heteroscedasticity problems in the established equation reduces the validity of the analysis results. For this reason, the existence of the heteroscedasticity problem in the equation should be determined. Modified The Breusch-Pagan / Cook-Weisberg test for heteroscedasticity was used for this determination. The test results are shown in the table below.

\section{Table 4: Heteroscedasticity Test Results}

\begin{tabular}{lc}
\hline & F Stats \\
\hline Equation 1 & 0,50 \\
\hline Equation 2 & 0,76 \\
\hline Equation 3 & 2,02 \\
\hline Equation 4 & 0,34 \\
\hline Equation 5 & 0,01 \\
\hline Equation 6 & 2,02 \\
\hline
\end{tabular}

$* \mathrm{P}<0,1 ; * * \mathrm{P}<0,05 ; * * * \mathrm{P}<0,001 ;$

$\mathrm{H}_{0}$ : there is constant variance

According to the results in table 4, The $\mathrm{H}_{0}$ hypothesis is accepted. Therefore, there isn't a heteroscedasticity problem in all equations.

\subsubsection{Autocorrelation}

In panel data analysis, if there is no unit effect on the variables, the possibility of catching autocorrelation problem decreases (Tatoğlu, 2012a: 203). It has already been stated that the unit effect cannot be determined with the data used in the study. Wooldridge (2002) test was also applied to determine the autocorrelation problem. The test results are given in the table below

\section{Table 5: Autocorrelation Test Results}

\begin{tabular}{lc}
\hline & F Stats \\
\hline Equation 1 & 1,737 \\
\hline Equation 2 & 0,001 \\
\hline Equation 3 & $946,45 * * *$ \\
\hline Equation 4 & 2,36 \\
\hline Equation 5 & 0,008 \\
\hline Equation 6 & $201,44 * * *$ \\
\hline
\end{tabular}

* $\mathrm{P}<0,1$; ** $\mathrm{P}<0,05$; *** $\mathrm{P}<0,01$;

$\mathrm{H}_{0}$ : There is no autocorrelation 
According to the test results obtained, H0 hypothesis is rejected for equation 3 and 6 . Therefore, the autocorrelation problem was found in this equation. According to this, there is a problem of heteroscedasticity and autocorrelation problems in equation 3 and equation 6. Arellano, Froot and Rogers's robust predictor method can be used to solve these problems (Tatoglu, 2012a: 246). Therefore, in order to overcome these problems in the analysis, Arellano, Froot and Rogers's robust predictor method is used.

\subsection{Analysis of Data}

In this study, firstly, it is investigated to the effect the change in hazelnut prices in Turkey and Italy on the financial performance of the companies operating in hazelnut field. Selling, exporting and net profit variables are used as financial performance variables of firms. The results of the analysis made for this purpose are given in the table below.

Table 6: The Effect of Hazelnut Prices on the Financial Performance of the Companies

\begin{tabular}{lcccc}
\hline Variables & Sales (DLPS) & Export (DLEXP) & Net Profit (DLMNP) \\
\hline DLHPT & $0,476^{* * *}$ & $0,833^{* *}$ & DLef. \\
\hline DLHPI & $0,478^{* * *}$ & $-0,038$ & DLHPI & -1391988 \\
\hline Constant & $0,041^{* * *}$ & $0,031^{*}$ & Constant & $-0,0081315$ \\
\hline R Square & $0,23(\% 23)$ & $0,7(\% 07)$ & R Square & $0,02(\% 2)$ \\
\hline F Stats & $40,9(0,000)$ & $13,3(0,000)$ & F Stats & $0,55(0,58)$ \\
\hline
\end{tabular}

$* \mathrm{P}<0,1 ; * * \mathrm{P}<0,05 ; * * * \mathrm{P}<0,01$;

According to the analysis results, the increase in hazelnut prices in Turkey has a positive effect on both sales and export revenues. However, there is no impact on the net profit performance. Moreover, the change in Italian hazelnut prices only affects the sales performance of firms. There is not any impact on export and net profit performances. On the other hand, the effect of variables on sales performance was around $23 \%$, while the effect on export performance was determined as $7 \%$. In this context, $\mathrm{H}_{1 \mathrm{a}}$ and $\mathrm{H}_{1 \mathrm{~b}}$ hypotheses are accepted and $\mathrm{H}_{1 \mathrm{c}}$ hypotheses are rejected. Thus, it can be said that the $\mathrm{H}_{1}$ hypothesis is largely acceptable. Accordingly, nuts companies in Turkey, they can request an increase in the price of hazelnuts to increase their selling and export revenues.

Secondly, the effect of exchange rate changes on firms' financial performance is examined. In addition, it is tried to examine that the moderator effect of the change in the exchange rate on the relationship between the financial performances of the firms and the hazelnut prices in Turkey. The analysis results are given below. 
Table 7: Normal and Moderator Effect of Foreign Exchange Rate

\begin{tabular}{lcccc}
\hline Variables & Sales (DLPS) & Export (DLEXP) & \multicolumn{2}{c}{ Net Profit (DLMNP) } \\
\hline DLHPT & $0,982 * * *$ & $1,42 * * *$ & DLHPT & 0,100 \\
\hline DLHPI & 0,177 &,- 423 & DLHPI & 0,088 \\
\hline DLER &,- 054 &,$- 244 *$ & DLER & $-0,068$ \\
\hline DLHPT $*$ DLER & $-2,291 * * *$ & $-2,975 * * *$ & DLHPT*DLER & $-1,128$ \\
\hline Constant &, 008 &, 040 & Constant & $-0,018$ \\
\hline R Square & $0,30(\% 30)$ & $0,11(\% 11)$ & R Square & $0,02(\% 2)$ \\
\hline F Stats & $35,48(0,000)$ & $18,23(0,000)$ & F Stats & $0,30(0,87)$ \\
\hline
\end{tabular}

$* \mathrm{P}<0,1 ; * * \mathrm{P}<0,05 ; * * * \mathrm{P}<0,01$;

According to the analysis results obtained, the increase in the exchange rate has a positive effect on the sales performance of the firms. In addition, the increase of the exchange rate affects negatively on the relationship between the hazelnut prices and the firms' sales performance, in Turkey. In this equation, the independent variables are found to be $24 \%$ effective on the dependent variable. On the other hand, direct or moderator effect of exchange rate on export revenues and net profit could not be determined. According to these results, $\mathrm{H}_{2 \mathrm{a}}$ and $\mathrm{H}_{3 \mathrm{a}}$ hypotheses were accepted and other hypotheses were rejected. Hence, the acceptability of $\mathrm{H}_{2}$ and $\mathrm{H}_{3}$ hypotheses can be said to be partial. According to these results, in the market where the exchange rate is high, the desire of companies for increasing the price of hazelnuts may be lower.

The moderating effect of the exchange rate relationship between the hazelnuts prices and the sales revenues in Turkey has been determined. Figure 7 generated for this effect is shown below. 
Figure 7: Exchange Rate Moderator Impact Graph on Relationship between Hazelnut Prices and Sales Revenues

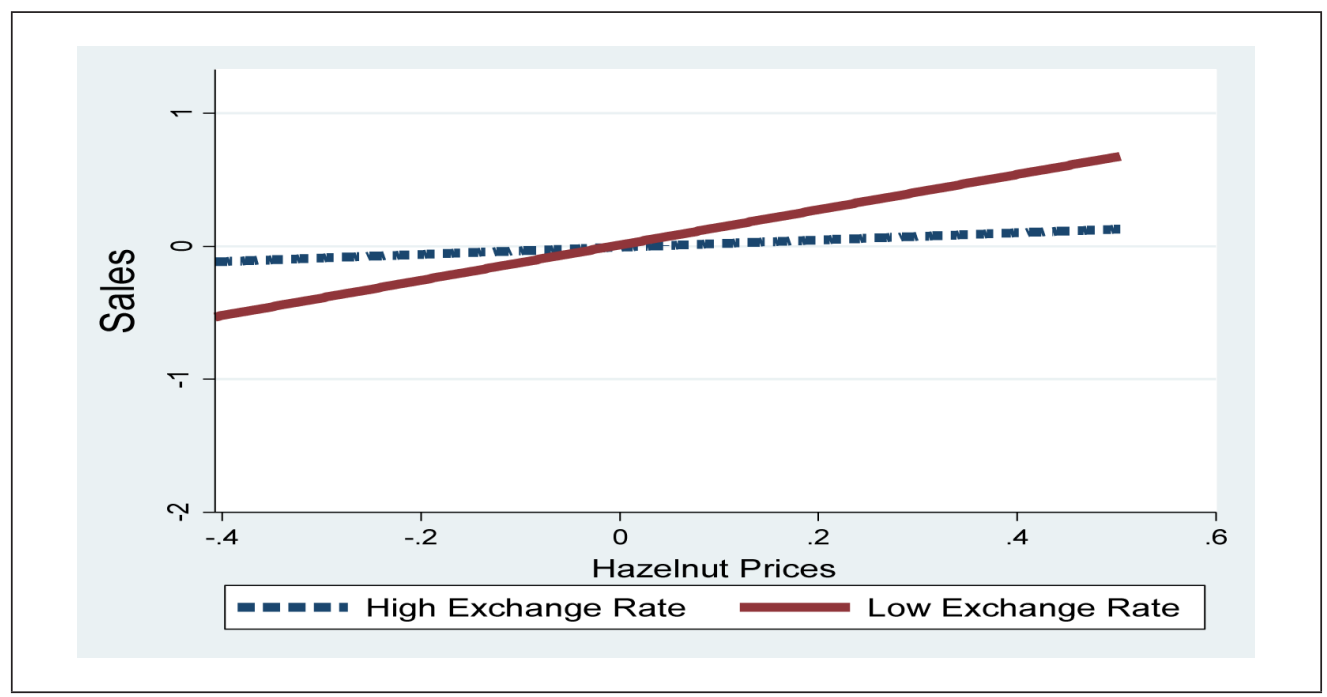

The straight line in the graph represents the relationship between the nut prices and the sales revenues when the exchange rate is low. The dashed line represents the relationship between the nut prices and the sales revenues when the exchange rate is high. When both lines are examined, while the effect of hazelnut prices on sales revenues is higher in the case of the low exchange rate, the increase in exchange rate reduces the effect of hazelnut prices on sales revenues In addition, the table showing the meaning level of the lines in the chart is given below. Accordingly, both are meaningful.

Table 8: The Lines Significance Table of Relationship between Sales Revenues and Hazelnut Prices in Different Foreign Exchange Rates

\begin{tabular}{cccccc}
\hline & Moderator Impact Status & Beta & St. Error & T. Stats & P Value \\
\hline \multirow{2}{nyyyyy}{ High Exchange Rate } & .2708095 & .1475763 & 1,84 & 0.068 \\
\cline { 2 - 6 } & Low Exchange Rate & 1.325622 & .1494109 & 8.87 & 0.000 \\
\cline { 2 - 6 } & Difference & -1.054813 & .183685 & -5.74 & 0.000 \\
\hline
\end{tabular}

As you can see from Table 8, all the lines in the graph are significant.

On the other hand, the moderator effect of the exchange rate relationship between the hazelnuts prices and the export revenues in Turkey has been determined. Figure 8 generated for this effect is shown below. 
Figure 8: Exchange Rate Moderator Impact Graph on Relationship between Hazelnut Prices and Export Revenues

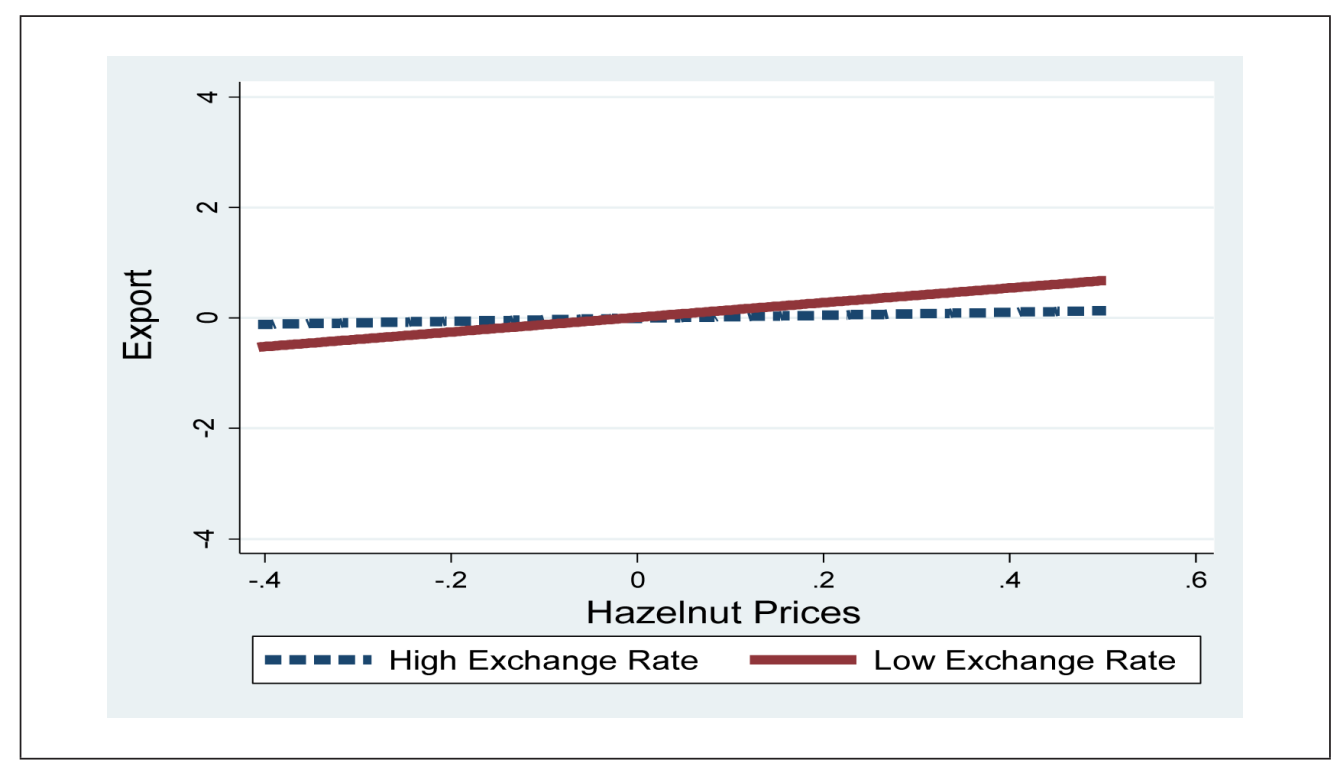

According to this graph, the relationship between hazelnut prices and export performance is higher when the exchange rate is low. When the exchange rate rises, this relationship decreases. Therefore, the negative effect of the exchange rate on this relationship is also seen in the graph.

The line of the low exchange rate is significant, but the line of the high exchange rate is not significant on the graph. However, it can be said that the graph is meaningful because of the differences is significant.

Table 9: The Lines Significance Table of Relationship between Export Revenues and Hazelnut Prices in Different Foreign Exchange Rates

\begin{tabular}{clcccc}
\hline & Moderator Impact Status & Beta & St. Error & T. Stats & P Value \\
\hline \multirow{2}{*}{ High Exchange Rate } & .339757 & .3026637 & 1.12 & 0.263 \\
\cline { 2 - 6 } & Low Exchange Rate & 1.214711 & .3159823 & 3.84 & 0.000 \\
\cline { 2 - 6 } & -.8749538 & .3755712 & -2.33 & 0.021 \\
\hline
\end{tabular}

\subsection{Long-term Effect Test (Robustness Test)}

The long-term relationship between two variables is examined by cointegration tests (Gujarati, 2009: 730). This will also help explain whether there is a long-term relationship between the variables studied above. Pedroni and Kao cointegration tests will be used for longterm relationship studies. 
The Pedroni panel cointegration test is a very popular method of analysis used by many people in the literature. This method of analysis is based on 7 test systems (Pedroni, 2004: 597). Kao (1999) and Kao \& Chiang (2000) proposed panel tests for cointegration that can be seen, in the context of panel data, as a generalization of the Dickey-Fuller (DF) and Augmented Dickey-Fuller (ADF) tests (Gutierrez, 2003:105). In the table below, firstly, the results of longterm impact analysis about equation 1 are given

Table 10: Cointegration Test Results for Equation 1

\begin{tabular}{|c|c|c|}
\hline \multicolumn{3}{|c|}{ Production Sales: Hazelnut Price (Turkey), Hazelnut Price (Italy) } \\
\hline \multicolumn{3}{|c|}{ Pedroni Panel Cointegration Test Results } \\
\hline & Intercept & No intercept or trend \\
\hline \multicolumn{3}{|c|}{ Statistics } \\
\hline Panel v-Statistic & $-0,301$ & 1,103 \\
\hline Panel rho-Statistic & $-3,607 * * *$ & $-4,977 * * *$ \\
\hline Panel PP-Statistic & $-8,141 * * *$ & $-8,216^{* * *}$ \\
\hline Panel ADF-Statistic & $-7,207 * * *$ & $-7,026 * * *$ \\
\hline Group rho-Statistic & $-0,957$ & $-1,919 * *$ \\
\hline Group PP-Statistic & $-0,832 * * *$ & $-9,431 * * *$ \\
\hline Group ADF-Statistic & $-7,005 * * *$ & $-6,753 * * *$ \\
\hline
\end{tabular}

\begin{tabular}{lc}
\hline & Kao Panel Cointegration Test Results \\
\hline & T- Statistic \\
\hline ADF & $-5,710^{* * *}$ \\
\hline Residual variance & 0,299 \\
\hline HAC variance & 0,006 \\
\hline
\end{tabular}

$* \mathrm{P}<0,1 ; * * \mathrm{P}<0,05 ; * * * \mathrm{P}<0,01$;

As can be seen from Table 9, Pedroni's no intercept or trend model has found longterm cointegrated in 6 of 7 cointegration tests. Kao's test also found a long-term relationship. Accordingly, there is a long-term relationship between sales performance of companies in the hazelnut sector and hazelnut price in Turkey and in Italy.

FMOLS analysis was conducted to learn the details of this relationship. The results obtained are given in table 10 .

Table 11: The Result of Panel Fully Modified Least Squares Analysis (FMOLS) For Equation 1

Dependent Variable: Production Sales

\begin{tabular}{lccc}
\hline Independent Variable & Coefficient & T-statistic & Adj. R-Squared \\
\hline Hazelnut Price (Turkey) & 0,634 & $5,457 * * *$ & \multirow{2}{*}{$0,22(\% 22)$} \\
\cline { 1 - 3 } Hazelnut Price (İtaly) & 0,349 & $3,142 * * *$ & \\
\hline
\end{tabular}

$* \mathrm{P}<0,1 ; * * \mathrm{P}<0,05 ; * * * \mathrm{P}<0,01$; 
As shown in Table 10, hazelnut prices in both Italy and Turkey affected positively on the sales of the companies working in the field of nuts in Turkey. The explanatory power of this effect is $22 \%$.

The result of cointegration test for the variables in Equation 2, have been examined in the previous title and found a significant relationship, are given table 11

Table 12: Cointegration Test Results for Equation 2

Export: Hazelnut Price (Turkey), Hazelnut Price (Italy)

Pedroni Panel Cointegration Test Results

\begin{tabular}{|c|c|c|}
\hline & Intercept & No intercept or trend \\
\hline & \multicolumn{2}{|c|}{ Statistics } \\
\hline Panel v-Statistic & $-0,338$ & 1,060 \\
\hline Panel rho-Statistic & $-3,017 * * *$ & $-4,133 * * *$ \\
\hline Panel PP-Statistic & $-8,200 * * *$ & $-7,354 * * *$ \\
\hline Panel ADF-Statistic & $-7,763 * * *$ & $-7,182 * * *$ \\
\hline Group rho-Statistic & $-1,504 * *$ & $-2,181 * *$ \\
\hline Group PP-Statistic & $-8,926 * * *$ & $-9,187 * * *$ \\
\hline Group ADF-Statistic & $-8,357 * * *$ & $-8,612 * * *$ \\
\hline
\end{tabular}

Kao Panel Cointegration Test Results

\begin{tabular}{lc}
\hline & T- Statistic \\
\hline ADF & $-8,896 * * *$ \\
\hline Residual variance & 1,725 \\
\hline HAC variance & 0,736 \\
\hline
\end{tabular}

$* \mathrm{P}<0,1 ; * * \mathrm{P}<0,05 ; * * * \mathrm{P}<0,01$;

As can be seen from Table 11, Pedroni's no intercept or trend model has found longterm cointegrated in 6 of 7 cointegration tests. Kao's test also found a long-term relationship. Accordingly, there is a long-term relationship between the export performance of companies in the hazelnut sector and hazelnut price in Turkey and in Italy. FMOLS test results showing the details of this relationship are given below.

Table 13: The Result of Panel Fully Modified Least Squares Analysis (FMOLS) for Equation 2

Dependent Variable: Export

\begin{tabular}{lccc}
\hline Independent Variable & Coefficient & T-statistic & Adj. R-Squared \\
\cline { 1 - 3 } Hazelnut Price (Turkey) & 0,996 & $3,109 * * *$ & \multirow{2}{*}{$0,047(\% 4,7)$} \\
\cline { 1 - 3 } Hazelnut Price (Italy) & 0,224 & 0,736 & \\
\hline
\end{tabular}

* $\mathrm{P}<0,1 ; * * \mathrm{P}<0,05 ; * * * \mathrm{P}<0,01$; 
According to the results are given table 12, the long-term effect of the price of hazelnut in Turkey on export revenues of the company have been identified. The explanatory power of this effect is $4.7 \%$.

According to the results in Tables 10 and 12, predetermined hazelnut prices can help companies estimate selling and exporting revenues. In addition, firms can regulate their operating policies according to these estimates.

The results of the Cointegration Test Results of the 4th and 5th equations, in which the moderator effect is determined, are given in table 13 .

Table 14: Cointegration Test Results for Equation 4 and 5

\begin{tabular}{|c|c|c|c|c|}
\hline \multicolumn{5}{|c|}{ Pedroni Panel Cointegration Test Results } \\
\hline \multicolumn{3}{|c|}{ PS : HPT, HPİ, ER, ER*HPT } & \multicolumn{2}{|c|}{ EXP : HPT, HPİ, ER, ER*HPT } \\
\hline & Intercept & $\begin{array}{l}\text { No intercept or } \\
\text { trend }\end{array}$ & Intercept & $\begin{array}{l}\text { No intercept or } \\
\text { trend }\end{array}$ \\
\hline & \multicolumn{4}{|c|}{ Statistics } \\
\hline Panel v-Statistic & $-0,942$ & 0,099 & $-1,748$ & $-2,016$ \\
\hline Panel rho-Statistic & $-0,074$ & $-1,348 *$ & $-0,394$ & 1,197 \\
\hline Panel PP-Statistic & $-8,798 * * *$ & $-8,874 * * *$ & $-8,986 * * *$ & 0,084 \\
\hline Panel ADF-Stat. & $-8,188 * * *$ & $-8,197 * * *$ & $-8,992 * * *$ & 0,053 \\
\hline Group rho-Stat. & 1,684 & 1,185 & 1,484 & 1,323 \\
\hline Group PP-Statistic & $-10,554 * * *$ & $-9,101 * * *$ & $15,805 * * *$ & $-5,647 * * *$ \\
\hline Group ADF-Stat. & $-8,859 * * *$ & $-8,075^{* * *}$ & $10,290 * * *$ & $-5,761 * * *$ \\
\hline \multicolumn{5}{|c|}{ Kao Panel Cointegration Test Results } \\
\hline $\mathrm{ADF}$ & \multicolumn{2}{|c|}{$-7,447 * * *$} & \multicolumn{2}{|r|}{$-8,910$} \\
\hline Residual variance & \multicolumn{2}{|r|}{0,282} & \multicolumn{2}{|r|}{1,624} \\
\hline HAC variance & \multicolumn{2}{|r|}{0,057} & \multicolumn{2}{|r|}{0,685} \\
\hline
\end{tabular}

$* \mathrm{P}<0,1 ; * * \mathrm{P}<0,05 ; * * * \mathrm{P}<0,01$;

According to the results shown in Table 13, Pedroni's no intercept or trend model has found long-term cointegrated in 5 of 7 cointegration tests for equation 4 . In addition, the longterm relationship is determined as a result of the Kao Cointegration test for both equations, According to these results, it can be said that there is a long-run relationship between the variables in both equations. FMOLS test results for determining the details of the obtained results are given in table 14 . 
Table 15: The Result of Panel Fully Modified Least Squares Analysis (FMOLS) for Equation 4 and 5

\begin{tabular}{|c|c|c|c|c|c|c|}
\hline Dependent Variable: & & Production & Sales & & Expor & \\
\hline Independent Variable & Coef. & T-stat. & Adj. R-Squ. & Coef. & T-stat. & Adj. R-Squ \\
\hline HPT & 1,195 & $8,681 * * *$ & \multirow{4}{*}{$0,30(\% 30)$} & 1,184 & $2,853 * * *$ & \multirow{4}{*}{$\begin{array}{c}0,081 \\
(\% 8,1)\end{array}$} \\
\hline HPI & $-0,078$ & $-0,672$ & & 0,030 & 0,087 & \\
\hline ER & $-0,112$ & $-0,899$ & & $-0,206$ & $-0,560$ & \\
\hline HPT*ER & $-2,832$ & $-5,782 * * *$ & & $-2,856$ & $-1,929 * *$ & \\
\hline
\end{tabular}

$* \mathrm{P}<0,1 ; * * \mathrm{P}<0,05 ; * * * \mathrm{P}<0,01$;

The results shown in Table 14 are similar to the panel regression test results. Accordingly, moderator effect has been determined in both equations. In this context, it can be said that there is a negative long-term moderator effect of the exchange rate on the relationships between the sales revenue and the hazelnut price in Turkey. The same effect also available between the export revenue and the hazelnut price. These results are consistent with the moderator effect graphs given in the previous section.

When the long-term negative moderator effect of the exchange rate is evaluated together with the above graphs, firms can continue their activities without being sensitive to the changes in hazelnut prices when the exchange rates are high.

\section{Conclusions}

Hazelnut has been an important export and a revenue source for Turkey for a long time. The most hazelnut production in the world and Turkey is in the Black Sea Region of Turkey. Hazelnut prices are determined differently each year and generally depending on the yield. This situation directly affects the regional economy. According to the analysis results made in this context, the increase in hazelnut prices affects positively the sales and export revenues of firms. According to this result, high prices of hazelnuts can cause gain more not only the manufacturer but also the firms and the country's economy. In addition, no effect on the net profit could be determined.

It can be said that the hazelnut industry in the world market is in Turkey's monopoly. This helps explain why rising prices have a positive impact on firm sales and export revenues. The annual average hazelnut needs of foreign firms or countries are determined, and they import the approximately same amount of products every year. Therefore, high product prices in Turkey, cause the companies in Turkey to generate more revenue. Although high hazelnut prices have a positive effect on sales and export revenues, they also increase the input costs. Because of this, the high prices of hazelnuts do not affect the net profits of the firms in Turkey.

In addition, it can be said that there are many other expense factors affecting the net profits of firms, which is another reason why the change in hazelnut price has no positive effect on net profit. These include financial expenses, other extraordinary expenses, and administrative expenses. 
In order to improve the financial performance of firms in Turkey, instead of hazelnuts exported as raw material, they should process it and then export by converting a high-value product. In addition, over the years when the harvest is high, hazelnut must be stored with appropriate storage techniques and should be thrown into the market for years when the harvest is lower. Thus, both the effect of environmental risk can be reduced and price stability may have been achieved.

In addition, in the research, it is determined that the impact of the exchange rate, which varies according to the years, on the relationship between hazelnut prices and firm revenues (sales and export). Accordingly, when the exchange rate is low, change in hazelnut prices affects sales and export revenues more. When the exchange rate is high, this relationship decreases. Although world hazelnut prices are traded in dollars, the increase in the exchange rate during the period is not reflected in hazelnut prices. This reduces the positive effect of hazelnut prices on sales and export revenues.

Foreign importer companies tended to vertical integration by purchasing company in Turkey because of the great influence of Turkey in the world hazelnut market and constantly changing their transaction costs. In this context, the most important hazelnut exporter companies in Turkey has been purchased by foreign firms in recent years. Regarding this situation, there is a serious allegation that a foreign firm has $60 \%$ of the Turkey hazelnut market. This may also affect the pricing of hazelnuts. Therefore, this situation reveals the possibility that hazelnut prices will able to be determined by foreign companies in the future. Especially in the last few years, important claims about this issue have been put forward. This situation may also be investigated. On the other hand, the limitation of the study is that the examination was made only on large and medium-sized companies.

\section{References}

Akseki, U. (2014). Econometric analysis of world hazelnut demand: Panel data analysis (19702010). Ege Strategic Research Journal, 5(1), 65-78.

Banker, R. D., Lee, S. Y., Potter, G., \& Srinivasan, D. (2000). An empirical analysis of continuing improvements following the implementation of a performance-based compensation plan. Journal of Accounting and Economics, 30, 315-350.

Bayramoğlu, Z., \& Gündoğmuş, E. (2007). Analysis of world hazelnut market. Journal of Ekonomik Yaklaşım, 18(65), 71-89.

Bernard, A.B., \& Jensen, J. B. (1999). Exceptional exporter performance: Cause, effect, or both. Journal of International Economics, 47, 1-25.

Core, J. E., Holthausen, R. W., \& Larcker, D. F. (1999). Corporate governance, chief executive officer compensation, and firm performance. Journal of Financial Economics, 51, 371 406.

Çamoğlu, S. M., \& Saka, G. (2012, November). Türkiye findık ihracat piyasasında dış ticareti etkileyen faktörlerin analizi.The Turkish Economic Association Third International Conference on Economics, İzmir/Turkey, 1-14.

Çelik, Ş. (2014). The analysis of production - price relation in hazelnuts shelled production using Koyck model of Turkey. Turkish Journal of Agricultural and Natural Sciences, $1(4), 524-530$. 
Erdal, G., \& Uzunöz, M. (2008). The Causalıty relationshıp among hazelnut prices of Turkey and Europe and exchange rate. Journal of Agricultural Faculty of Uludag University, 22(2), 47-56.

Fidan, H., \& Şahinli, M.A. (2010). Profit level and price fixing in hazelnut production. The Journal of Animal \& Plant Sciences, 20(2), 117-122.

General Secretariat of Black Sea Exporters Associations, Access Date: 14.07.2017 http://www . kib.org.tr/tr/birlikler-findik-ve-mamulleri-ihracatcilari-birligi-findik-hakkinda-findikcesitleri.html.

Gujarati, D. N. (2009). Temel ekonometri, (Çev: Ümit Şenesen), İstanbul: Literatür Yayıncılık.

Gutierrez, L. (2003). On the power of panel cointegration tests: A Monte Carlo comparison. Economics Letters, 80, 105-111.

Güney, O.İ. (2014). Turkish hazelnut production and export competition. Yuzuncu Yll University Journal of Agricultural Sciences, 24(1), 23-29.

Hatırlı, S.A., Öztürk, E., \& Aktaş, A.R. (2008). An analysis of price transmission in hazelnut market. Journal of Akdeniz university faculty of agriculture, 21(1), 139-143.

Hoque, Z., \& James, W. (2000), Linking Balancing scorecard measures to size and market factors: Impact of organizational performance. Journal of Accounting Management Research, 12, 1-17.

International Nut\&Dried Fruit (INC). Access Date: 01.07.2017 http://www.nutfruit.org/whatwe-do/publications/inc-magazine.

Öztürk, D., \& Arıcı, Y.K. (2017). Analysis of production and marketing problems of hazelnut producers: A case of Samsun province. Ordu University Journal of Social Sciences Research, 7(1), 21-34.

Park, A., et al. (2009). Exporting and firm performance: Chinese exporters and the Asian financial crisis. NBER Working Paper Series, National Bureau of Economic Research, $1-50$.

Pedroni, P. (2004). Panel cointegration: Asymptotic and finite sample properties of pooled time series tests with an application to the PPP hypothesis. Cambridge University Press, Econometric Theory, 20(3), 597-625.

Siray, E. (2013). Hazelnut production and trade status. Hazelnut Research Institute, Training Notes, Giresun, 1-8.

Tatoğlu, F. Y. (2012a). Panel veri ekonometrisi (stata uygulamalı). ISBN: 9786053330035, 1. Baskı, İstanbul: Beta Yayınları

Tatoğlu, F. Y. (2012b). Illeri panel veri analizi (stata uygulamalı). ISBN: 9786053330394, 1. Baskı, İstanbul: Beta Yayınları.

Trabzon Exchange Commodity (2014). Project for increasing yield and quality in hazelnut: Hazelnut handbook Access Date: 23.07.2017, http://www.kalitelifindik.org/index. php?sayfa=findik_el_kitabi.138\&d=tr

Turkish Chamber of Agricultural Engineers (UCTEA). (2016). Hazelnut reports 2016. Access Date: 23.07.2017,http://www.zmo.org.tr/genel/bizden_detay. php?kod=26370\&tipi $=17 \&$ sube $=0$

Turkish Grain Board (2016). The 2015 year hazelnut sectorial report. Access Date: 20.01.2017.

Zaman, M. (2004). Geographical distribution and production of hazelnut gardens in Turkey. Eastern Geographical Review, 9(11), 49-92. 